\title{
Multi-Stakeholder Perspectives of Environmental Accountability Practices in the Mining Sector
}

\author{
George Tackie \\ Department of Accounting, University of Cape Coast, Ghana \\ University Post Office, UCC, Cape Coast, Ghana
}

Tel: 233-24-437-8894Ｅ-mail: gtackie@ucc.edu.gh

Received: November 16, 2020 Accepted: December 2, 2020 Published: December 30, 2020

doi: 10.5296/ijafr.v10i4.17945

URL: https://doi.org/10.5296/ijafr.v10i4.17945

\begin{abstract}
This paper analyses environmental accountability practices (EAP) in the mining sector from the perspectives of multi-stakeholders. The study adopts a purely qualitative approach to research in terms of research method, data collection and data analysis. Interview data was gathered from a sample of twenty-one predominantly large-scale mining firms in Ghana. Based on responses from the interview respondents, themes from the literature and empirical material, stakeholders' perspectives were analysed regarding (1) motivations for EAP; (2) effectiveness of EAP; (3) performance assessment based on EAP; and (4) stakeholder engagements regarding EAP. This paper analyses EAP in Ghana's mining industry from the viewpoint of multi-stakeholders - regulatory bodies, mining companies, environmental managers, community partners, environmental consultants, and mining association. The findings reveal the commonality of acceptable and responsible EAP that can lead to a 'win-win' situation for all stakeholders in the mining industry. Mining firms should increase their focus on practicing value-added EAP in all facets of mining operations. They should also strengthen their engagement with indigenes, and not only local elites, and align their EAP efforts with the immediate needs of the local communities. The novelty of this paper is the determination of the drivers (the 'why'), outputs (the 'how'), and outcomes (the benefits) of EAP which is missing in the EAP literature.
\end{abstract}

Keywords: Environmental accountability practices, Mining firms, Multi-stakeholder perspectives, Mining sector

\section{Introduction}

The mining sector has significantly gained a lot of public interest and attention both locally and globally, due to the nature of the environmental and social accountability issues. 
Although the industry accrues many advantages, inappropriate and irresponsible mining activities have led to a drastic environment and resource depletion. To achieve a balance of such activities, environmental accountability practices (EAP) has become a must for industry players. Some contemporary businesses engage in sustainable strategies like green initiatives and EAP to demonstrate their accountability practices (Chaabane, Ramudhin, \& Paquet, 2011; Bendell \& Kearins, 2005). According to Peloza (2006) and Salam (2009), EAP increases sales revenue and capital share and improves customers' perceptions of a business. In this way, EAP acts as a strategic issue in modern competitive business (Salam, 2009).

The main reason an entity adopts EAP is to contribute to a better society and cleaner environment for a safe human living (European Commission, 2001; Hamann \& Kapelus, 2004; Velásquez, 2012). Over the years, the mining industry has been criticized for various gaps in implementing EAP even though the industry plays a vital role in both the local and global economy through the provision of basic raw materials and energy for many industries, including ceramics, electronics, metal, paper, plastics, and others (Vintró Sánchez et al., 2012). Unfortunately, unplanned expansion, environmental accidents, and direct disposal of wastewater have led to irreversible results like chemical leakage, acid mine drainage, soil contamination, threats to fisheries and activity, and land and water contamination, alongside its heinous health implications (Candeias, Ávila, Coelho, \& Teixeira, 2018; Kemp, Boele, \& Brereton, 2006).

For some time now, African countries with mining sectors have shifted their policy emphasis towards a primary objective of maximising tax revenue from mining over the long term, rather than pursuing other economic or political objectives (Akabzaa \& Darimani, 2001). The mining industry in Ghana cannot be considered an isolated phenomenon. Ghana was among the first sub-Saharan countries to embark on major economic reforms (Pickett \& Shaeeldin, 1990). From 1984 to date, there have been significant institutional development and policy changes to reflect the new paradigm, from the establishment of the Minerals Commission (MinCom) in 1984 and the promulgation of the Minerals and Mining Code in 1986 to the promulgation of the Small-Scale Mining Law in 1989 and the establishment of the Environmental Protection Agency (EPA) in 1994.

Over the past years, mining concession holders $(\mathrm{MCH})$ have applied portions of their profits to support national or local projects through EAP strategies (Ghana Chamber of Mines, 2016). Improved EAP trends within the mining sector have arisen out of pressures from civil society and non-governmental organisations (NGOs), rather than from the compliance efforts that the EPA has been able to exert. Violence in the sector is not unknown; for example, reports persist of security agents shooting people who trespass in mining areas. Several civil society organisations (CSOs) are advocating improved environmental governance, social protection, compensation for affected communities, and human rights in mining regions.

Many have questioned the real benefits accruing to the ordinary Ghanaian in the mining communities and the country as a whole, in the light of the extremely generous fiscal and other incentives given to $\mathrm{MCH}$ despite the harmful nature of their activities. Indeed, Ghana's mining sector has generally generated considerable social costs and negative impacts 
especially on the most vulnerable segments of the society like the rural poor, women, and children. It has been suggested that a thorough cost/benefit analysis of the resurgent mining sector would probably return a negative figure. This is because of such factors as the high level of fiscal incentives enjoyed by $\mathrm{MCH}$ and the high level of foreign exchange earnings they are allowed to retain in offshore accounts. Other relevant factors include the negative environmental impact of mining and the growing incidence of conflict between mining communities and their chiefs on one hand and mining companies on the other hand.

It is important to conduct a holistic view of stakeholders (Weng, Chen, \& Chen, 2015) in establishing appropriate EAP. MCHs should be interested in knowing what the key drivers are in establishing appropriate EAP. Are regulatory institutions such as the MinCom and the EPA the most influential and important stakeholders? How should MCH address the concerns of various stakeholders? In the present study, the stakeholder theory is employed as the lens to frame the approach to the study. The use of stakeholder theory is to obtain a complete view of the perspectives of key stakeholders in Ghana's mining industry. Based on responses from the interview respondents, themes from the literature and empirical material, one significant contribution of this study, is the attempt to classify various stakeholders as (1) regulatory stakeholders; (2) operational stakeholders; (3) community stakeholders; (4) internal stakeholders; and (5) interactional stakeholders.

Regulatory stakeholders comprise regulatory bodies (such as MinCom and EPA) as well as other government agencies. Operational stakeholders refer to mining concession holders $(\mathrm{MCH})$, predominantly made up of mining firms and contract miners. Community stakeholders are generally community partners - host communities and their leaders. Internal stakeholders consist of investors, management, mine workers, and suppliers. Interactional stakeholders are those who MCHs interact regularly with and who do not belong to any of the earlier classifications. They include mining association, media, and the public, affiliate and associate institutions, and external or global bodies.

Mining companies must initiate strategic stakeholder engagement practices that take into account the demands of multiple complex stakeholder groups. Studies on the stakeholder-firm relationship have focused on stakeholder influences. Very few studies have looked at the engagement approaches adopted by MCHs in addressing the concerns of powerful stakeholders who can influence corporate social and environmental accountability disclosures (Lu \& Abeysekera, 2014). Some studies have focused on EAP issues but were limited to industrial perspectives without considering the viewpoint of multi-stakeholders. This paper attempts to bridge this gap by analysing the EAP of Ghana's mining industry from the perspectives of multiple stakeholders. First, the paper assesses the stakeholder engagement practices of mining firms that are intended to address the socio-economic and environmental impact of the mining operations on communities in mining areas. Second, the paper also examines the expectations of stakeholders and how mining companies seek to prioritise these expectations.

The remaining sections of this paper are organized as follows. The next section presents a review of the theoretical and empirical literature on EAP in the mining sector and stakeholder 
engagement practices. Then, the paper presents the methodology, the empirical analyses, results, and discussions. Finally, the paper presents a summary of stakeholders' perspectives as well as the drivers, outputs, and outcomes of environmental accountability in Ghana's mining landscape. The paper concludes with implications for policy and practice.

\section{Literature Review}

\subsection{EAP in the Mining Sector}

In times past, mining was just an activity of exploiting a concession until natural resources were worn out. Then the mining concession holder would move to the next place where this process would be continued (Vintró Sánchez et al., 2012). Due to high pressure from the host communities, the mining industry integrated sustainable practices in their operations in the early 1980s (Esteves, 2008; Jenkins \& Yakovleva, 2006), but there is limited literature on mining firms that integrate EAP strategy. Hamann (2003) discussed sustainable development in mining companies and challenges encountered in the implementation of EAP in the South African mining industries. He also explored the combined role of companies, government, and civil society to promote effective and efficient EAP strategy.

From the literature, there are some papers on South African mining firms that have incorporated EAP strategy into their operations. Kemp, Owen and Van de Graaff, (2012) examined EAP in mining sectors and their audit cultures. They also explained the importance of audits to mining sectors for long term success and expressed internal accountability in the mining industry to promote social performance. Many studies (Fonseca, McAllister, \& Fitzpatrick, 2014; Murguia \& Bohling, 2013; Lodhia, 2012; Northey, Haque, \& Mudd, 2013) emerged with the sustainable reporting and environmental disclosures in mining sectors.

Some researchers have investigated different case studies in the mining sector. Solomon, Katz, and Lovel (2008) explored research policies and challenges in the Australian mining sector through a case study and identified current themes in the social dimension of mining based on values, drivers, and interpretations. Similarly, Campbell (2003) discussed governance factors, codes, and conduct, policy reforms in African mining sectors with the EAP perspective. Hamann and Kapelus (2004) investigated the African mining environment, and Vintró Sánchez et al., (2012) and Velásquez (2012) discussed the status of EAP in Catalan and Southern Ecuadorian Andes mining industries, respectively. Freitas and Magrini (2013) developed a multi-criteria decision making support system for sustainable water management in the Brazilian mining sector. Gomes et al. (2014) analysed the factors related to the management of sustainability in Brazilian mining companies.

Some studies have also focused on cleaner production and environment in the mining industry. Muduli et al. (2013) investigated barriers and behavioral factors of green supply chain management in Indian mining sectors. Ghose (2003) examined the techno-economic and socio-cultural characteristics of Indian small-scale mines and also the legislative measures for cleaner production in the mining sector. Ghose (2003) examined environmental management plans (EMP) in Indian small-scale mines.

From the literature, it was evident that analysis of EAP in Ghana's mining sector is yet to be 
given some prominence, and especially, from the perspective of multiple stakeholders.

\subsection{Drivers of EAP}

Haigh and Jones (2006) reviewed drivers of EAP, and they distinguished drivers as internal drivers, competitive drivers, external drivers, regulatory drivers, and considered other pressures and popular mobilizations. Hietbrink, Berens and Van Rekom (2010) explored EAP from a business purchasing context, as they mentioned factors such as the environmental impact of products and production processes, avoiding child labor, stimulating employee volunteerism, codes of conduct, and pressures from consumers as drivers of EAP strategies.

In the literature, the focus has been on societal and business drivers whereas, in contrast, Moon (2004) argues on the importance of government as a driver of EAP. Smith (2007) argues that customers are the real drivers of EAP by explaining ethical influences on customer behavior. Powell, Davies and Shearer (2009) analysed motivations of corporate social responsibility (CSR) in supply chains, and they listed reputation, brand image, market sales, risk management, corporate identity, pressures from customers, investors, and regulatory pressures. Carter and Jennings (2000) explored four drivers of EAP, namely: people-oriented organisational culture; organisational policies; employee initiatives; and pressures from external customers. Ogawa (2009) argued that codes of conduct are the main driver of EAP. He also explained this with Japanese transnational corporations.

According to Li and Chiang (2010), the reasons for EAP adoption are reputation, community relations, regulation, stakeholder willingness, public pressure, consumer pressure, business ethics, risk protection, competition strategy, market positioning, recruitment, political and social relationship, society roles, strategic advantage, supply chain efficiency, non-governmental organisations, industry, codes of conduct, environment for resources and social legitimacy. Majumdar and Nishant (2008) made a conceptual framework on EAP in large-scale organisations and debated about drivers like avoidance of child labor, risk minimisation, market opportunity, sustainability issue, reputation, job losses, customers, business partners, local communities, employees and the public.

Cruz and Wakolbinger (2008) discussed CSR in supply chain networks, where they discussed common drivers of CSR like external pressure, internal pressure, reputation, long term success, health and safety regulations, labour rights abuses, public awareness, managing risk, brand recognition, cost reduction, and customer loyalty. Some researchers have also investigated drivers of EAP such as globalization, reputation, legal sanctions, customer loyalty, reduced cost, reduced risk, and brand recognition.

\subsection{Stakeholder Perspectives of EAP}

The EAP literature offers several constructs for interpreting and applying EAP. To date, an understanding of EAP through stakeholders' perspectives of EAP remains fertile. Perhaps, the lack of common definition or the different understandings of what EAP encompasses (Karnani, 2011) leads to diverse outcomes. Moreover, not only are there diverse definitions or understandings, but stakeholder groups themselves vary as much as the expectations about EAP and the likely impacts by companies are concerned. 


\section{Mll Macrothink}

International Journal of Accounting and Financial Reporting

ISSN 2162-3082

2020, Vol. 10, No. 4

Wood and Jones (1995) identify three roles of stakeholders. First, stakeholders are the source of expectations for a company's performance. Secondly, they experience the effects of companies' activities and, thirdly, they evaluate companies' outcomes in terms of stakeholder expectations; and the effects on them. Of course, from a stakeholder perspective, EAP will be evaluated based on how a company meets the stakeholder demands and expectations. Thus, stakeholders will perceive EAP according to the stakeholders' demands and interests (Fiedler \& Kirchgeorg, 2007; Hillenbrand \& Money, 2007). In many cases, the diversity of stakeholders translates into a diversity of interests and objectives. These interests sometimes converge or diverge into confronting scenarios involving social, environmental, and economic domains (Steurer et al., 2005). In such circumstances, stakeholder perspectives about EAP are not only diverse across groups, but sometimes even within the same group.

\subsection{The Stakeholder Theory and the Social Capital Theory}

Whereas many new theories have evolved regarding EAP, the two most popular theories are the stakeholder theory and the social capital theory. The main theme of the stakeholder perspective focuses on managerial decision making in business environments, while the social capital theory deals with the gap between multiple disciplines from economics, sociology, and political science perspectives (Sen, 2011). The evolution of EAP started in 1960 but EAP concepts became more aggressive from 1990 onwards (Sen, 2011; Larsen, 2010). In this study, we draw extensively on the stakeholder theory in analyzing the perspectives of stakeholders on the state of EAP in Ghana's mining industry.

\section{Research Method}

This study adopts a purely qualitative approach to research in terms of research method, data collection, and analysis.

\subsection{Data Sources and Collection}

Primary data was sourced in the form of semi-structured interviews with twenty-one environmental managers, including a focus group discussion with key environmental officers of one of the mining firms. The data was collected over a four-month period from October 2017 to January 2018. Interviews were also conducted with officials from the Minerals Commission (MinCom), Environmental Protection Agency, Ghana Chamber of Mines, community partners, and environmental consultants.

From the onset, the intent was to interview all the environmental managers of all 108 large-scale companies which have been granted mining leases and/or exploration licenses by the MinCom as of 10th November, 2017. However, once sufficiency and saturation of information (Seidman, 2006 as cited by Tang-Lee, 2016) were achieved, the interviews ended at thirty-six, including a focus group discussion.

Gaining access to each environmental manager was a very difficult hurdle. Even with introductory letters obtained from the MinCom and from the Ghana Chamber of Mines (GCM), gaining access to the intended interviewees was very challenging. Personal references were employed to gain access to the next interviewee. 


\section{MIN Macrothink}

International Journal of Accounting and Financial Reporting

ISSN 2162-3082

The entire fieldwork for the data collection took almost four months. However, eight non-consecutive days were used to conduct the interviews spanning a total duration of 1,141 minutes (approximately 19 hours). The average time for each interview was 60 minutes. The interviews with the environmental managers of the mining firms surveyed were spread across six regions out of the then ten regions in Ghana.

Participants were identified from a list of registered mining firms obtained from the MinCom and purposively sampled to identify relevant players in the industry. The mining firms comprised in this research work, are recognised in the Ghanaian mining sector, ranging from exploration companies to those with mining leases, predominantly large-scale firms. Also included are locally owned and foreign-owned mining firms. The interviewees were similarly selected from the mining regions after a stakeholder mapping that identified and selected the following key stakeholder groups: regulatory bodies (i.e. MinCom, EPA), mining concession holders, environmental managers, community partners, environmental consultants, and mining association (i.e. Ghana Chamber of Mines). The categories of persons interviewed and their respective codes have been presented in Table 1.

Table 1. Category of interviewees and key informants

\begin{tabular}{lcc}
\hline Category interviewed & Number interviewed & Code \\
\hline Minerals Commission & 4 & MinCom \\
Environmental Protection Agency & 1 & EPA \\
Mining concession holders & 4 & $\mathrm{MCH}$ \\
Environmental managers & 21 & Ems \\
Community partners & 2 & $\mathrm{CP}$ \\
Environmental consultants & 3 & EC \\
Mining association & 1 & MA \\
Total & $\mathbf{3 6}$ & \\
\hline
\end{tabular}

Source: Field Data (2018)

First, meetings were arranged by telephone and face-to-face to discuss and inform potential participants about the scope of the project and the interview. All participants were assured of anonymity. This was done to ensure honest and direct answers based on experiences and perceptions. Interviewees provided their written consent prior to a tape-recording of interviews.

During the interview, participants were asked questions such as: What are the motivations for EAP in the mining industry? How do the mining firms demonstrate their EAP? What kinds of impact result from the mining industry? What relevant aspects of EAP are being addressed in the mining industry or what are those not being addressed? How often does the firm dialogue with the communities? How do mining companies act in a socially responsible manner? These questions guided the main objectives of this study and provided further discussion in a 
flexible and natural conversation that allowed for the introduction more questions when unforeseen and interesting areas emerged.

Almost all the interviews were conducted via face-to-face, except for two interviews which were conducted via telephone. Besides, seven interactions were held with duty bearers of regulatory bodies and the mining association. The potential for misinterpretation of the interviewees' responses was minimised by association with the interviewees in terms of cultural practices and by recording the interviews and transcribing them with the help of professional transcribers to eliminate bias. To ensure reliability, a thorough process of reflexivity was ensured where some of the possible threats including reactivity, respondent biases, and researcher biases were dealt with.

\subsection{Data Analysis}

This research adopted an inductively-based analytical approach to analyse the qualitative data (Saunders et al., 2009). The data were analysed through a purely manual and qualitative manner, where concepts or themes within the gathered data were identified. This technique allowed working with coded information to identify common themes and insights (Miles, Huberman, \& Saldana, 2014) as well as relationships between concepts amongst different stakeholder groups. Later, to assure analytic closure (Miles, Huberman, \& Saldana, 2014), coded material was reviewed and complemented with notes taken during the interview process. The processes required an in-depth analysis of interview data and involved a process of interpretation and creativity by the researchers to make the data more meaningful.

\section{Results and Discussion}

This section presents and discusses the findings of this study in four aspects. The first relates to the nature and classification of identifiable stakeholders in the mining industry. The second focuses on the analysis of EAP in Ghana's mining industry. The third deals with stakeholder engagement practices in the Ghanaian mining industry. The fourth aspect provides a summary of the stakeholder perspectives on EAP with respect to motivation for EAP, the effectiveness of EAP, firm performance assessment, and stakeholder engagements. The paper concludes by providing the drivers (the "why" of EAP), outputs (the "how" of EAP), and outcomes (the "benefits") of EAP in the mining industry.

\subsection{Stakeholders in the Mining Industry}

In the mining industry, several stakeholder groups have been identified. Table 2 presents the various stakeholders in Ghana's mining industry and their classification. The classification was based on empirical material from the interview respondents and themes from the literature. Regulatory stakeholders comprise regulatory bodies (such as MinCom and EPA) as well as other government agencies. Operational stakeholders refer to mining concession holders $(\mathrm{MCH})$, predominantly made up of mining firms, and contract miners. Community stakeholders are generally community partners - host communities and their leaders. Internal stakeholders consist of investors, management, mine workers, and suppliers. Interactional stakeholders are stakeholders who regularly interact with MCHs but do not belong to any of 


\section{Macrothink}

International Journal of Accounting and Financial Reporting ISSN 2162-3082

the earlier classifications. They include mining association, media, and the public, affiliate and associate institutions, and external or global bodies.

Table 2. Classification of stakeholders in the mining sector

\begin{tabular}{|c|c|c|}
\hline $\begin{array}{l}\text { Stakeholder } \\
\text { Category }\end{array}$ & $\begin{array}{l}\text { Stakeholder } \\
\text { Group }\end{array}$ & $\begin{array}{l}\text { Stakeholders } \\
\text { Involved }\end{array}$ \\
\hline \multirow{12}{*}{$\begin{array}{l}\text { Regulatory } \\
\text { Stakeholders }\end{array}$} & Primary & - Minerals Commission \\
\hline & Regulators & - Environmental Protection Agency (EPA) \\
\hline & & - Forestry Commission \\
\hline & Secondary & - Water Resources Commission \\
\hline & Regulators & - Lands Commission \\
\hline & & - Ghana Revenue Authority \\
\hline & & - Ministry of Lands and Natural Resources \\
\hline & $\begin{array}{l}\text { Government } \\
\text { agencies }\end{array}$ & $\begin{array}{l}\text { - Ministry of Environment, Science, Technology, } \\
\text { and Innovation }\end{array}$ \\
\hline & & - Ministry of Finance \\
\hline & & $\begin{array}{l}\text { - Metropolitan, Municipal and District } \\
\text { Assemblies }\end{array}$ \\
\hline & & - Arms of Government \\
\hline & & - Office of the Administrator of Stool Lands \\
\hline \multirow{5}{*}{$\begin{array}{l}\text { Operational } \\
\text { Stakeholders }\end{array}$} & & - Commercial production firms \\
\hline & Mining & - Non-commercial production firms \\
\hline & Firms & - Pre-production firms \\
\hline & & - Exploration/prospecting firms \\
\hline & & - Contract mining firms \\
\hline \multirow{4}{*}{$\begin{array}{l}\text { Community } \\
\text { Stakeholders }\end{array}$} & & - Host communities \\
\hline & Community & • Chiefs \\
\hline & partners & - Community Interest Groups \\
\hline & & - Opinion leaders \\
\hline \multirow{6}{*}{$\begin{array}{c}\text { Internal } \\
\text { Stakeholders }\end{array}$} & & - Shareholders \\
\hline & Investors & - Foreign Direct Investors \\
\hline & & - Private Investors \\
\hline & Management & - Directors and Top management \\
\hline & Mineworkers & $\begin{array}{l}\text { - Permanent and Contract employees of mining } \\
\text { firms }\end{array}$ \\
\hline & Suppliers & - Service providers \\
\hline
\end{tabular}




\section{Interactional}

Stakeholders

Mining
association

- Ghana Chamber of Mines; Ghana Chamber of Commerce

- Association of Ghana Industries

- Ghana Extractive Industries Transparency Initiative

Source: Author's construct based on documentary analysis and interview data (2018)

\subsection{EAP in Ghana's Mining Industry}

Environmental accountability practices (EAP) of mining firms, as defined in this study, refers to a set of strategies, policies, and actions adopted by mining firms to demonstrate their responsibility to mitigate the negative impacts of their mining activities on their host communities, and appropriately reporting on these to their key stakeholders. It has become very difficult for most firms to operate smoothly in the absence of EAP (Idowu, 2009; Roome, 2005; Larsen, 2010). As a result, this paper sought views from stakeholders, as to the activities that mining firms engage in to show their commitment to EAP. Before addressing the issue of EAP, respondents were asked about their general opinion on the importance of mining activities in the mining areas. Many believe that the existence of the mines in their communities has given them a lot of benefits. Some asserted that:

"It is good because it has offered a lot of employment to the youth in the area. Without such employment, life could have been very unbearable" - CPI.

"In one way they are being helpful, they are putting lots of projects, examples schools, clinics, community centres, etc. On the other hand, they are acquiring all our land which is meant for farming. But overall, the benefits will be positive”- CP2.

"I will say in general when mining companies are located in an area it gives employment to the inhabitants of the community. The only problem I will say is that it comes with environmental problems which will be difficult to deal with. For example, 
when the land and water bodies are destroyed it will be very difficult if not impossible to reclaim it" - CP1.

"In my view, the mining companies do help us very much. In our community, we can boast of the community centre which is yet to be completed. They have also provided drinking water to us as well as granting some scholarships to our kids. I will say that the mining companies help the community to some extent but not as we want" - CP2.

"Mining sustains a lot of us. If I'm not lying about $70 \%$ have been employed through mining. Even if you are not directly employed by the mother company one can be employed by the sub-contractors. Families can pay their children school fees and cater for them" - CP1.

In terms of mining companies engaging in responsible and sustainable mining activities to demonstrate their environmental accountability, some respondents observed that:

"Mining in this area was supposed to be done underground. Later, there were many discussions on the introduction of surface mining. Surface mining will bring a lot of damage to the land but the government finally agreed. What we have been hearing are the blasting and the rest, and this is very bad and most of us have a lot of worries" - CP1.

"Yes. I will say it's important to this area because the gold is here and we thank God. The only problem is that it should be done responsibly so that we can benefit" - CP2.

Despite the benefits of mining activities to host communities, some respondents also believe that mining has come with a heavy price to pay in terms of the degradation of the river bodies and farmland. One of the topmost environmental problems that the respondents were very much concerned about is the impact of spillovers and disposal of large-volume wastes. Most respondents referred to tailings material as the greatest stream of waste from mining operations.

The EPA has impressed upon mining companies to maintain good environmental practices. This was visibly clear to see from the mining sites of most companies visited due to the protocols in place to ensure that waste is dealt with effectively and responsibly. For example, the management of AGAL, one of the mining firms surveyed, admitted that in September 2017, the EPA temporarily closed the firm's two metallurgical plants, the tailings storage facilities (TSFs), and all ancillary facilities, for 12 days, due to a discharge of untreated process water into the environment. Some of the mining companies have been signatories to the International Cyanide Management Code to emphasise their commitment to the management of mining waste.

Another environmental concern which was of great importance to the respondents is the issue of noise and vibration caused by mining operations. Many respondents of mining communities are very much concerned about noise pollution. They however pointed out that before "blasting" is done, adequate notice is given to community members. Regarding complaints from community members about cracks in their building because of "blasting" 
activities, it was noted that not all cracks in buildings were caused by mining activities. Other concerns expressed regarding the environment include "habitat destruction and reduction of biodiversity". Respondents were however less concerned about acid mine drainage, the environmental impact of products during and after use, and reinstatement of sites after mine closure.

In the literature, it is asserted that poor economic performance breeds poor EAP (Rokhmawati, Sathye, \& Sathye, 2015; Muhammad, Scrimgeour, Reddy, \& Abidin, 2015). Engaging in EAP is considered a cost inflator rather than achieving immense benefits. Some believe that relief from EAP will improve economic performance. One mining consultant agreed with this position with a remark that:

"Mining firms are not motivated to be environmentally friendly because of their economic performance. These firms are very much concerned about minimising cost and would usually view environmental responsibilities as cost inflators. Their thinking is that they will improve their economic position better when relieved of these environmental responsibilities" - EC2.

Some stakeholders are also of the view that demands from host communities are sometimes unrealistic. This is as a result of communities' misunderstanding of how the mining sector, and for that matter, mining firms operate. This is evident in the response from a mining concession holder $(\mathrm{MCH})$ who is even yet to begin commercial production.

"Per the government laws, you can do social responsibility after you have made profits. But it is the company that decides to do the short-term projects for the community, to ensure that the coexistence between the two parties is cordial... most of the communities we have provided for we have not even started mining there... But with such a step, the community may demand more than necessary, an attitude that can bring agitation between the two parties and collapse the company"- MCH3.

\subsection{Stakeholder Engagement Practices in the Mining Sector}

Findings from this study have revealed that, as a way of improving their relationships with mining communities, mining companies have established Community Consultative Community Meetings (CCCM). The CCCM meet formally and regularly, usually monthly, and informally, whenever necessary. The consultative committee is made up of the chief, a youth leader, a religious leader, a women's representative, a community-based organsiation (CBO) representative, and a leader from the farmers in the village.

Apart from the CCCM, some mining companies have their unique working committees for various purposes. At AGAIM, another large-scale mining firm surveyed, for instance, there is the Community Liaison Group (CLG), which comprises two selected executives from the CCCM, a representative for the NGOs, and a representative from the mine's Health, Safety, and Environment (HSE) Department. They meet quarterly. According to the HSE manager of AGAIM, there is also the Monitoring Advisory Group (MAG). He remarked:

"Besides the CLG, there is the MAG, which has an independent chairperson, 
composed of representatives from two NGOs, a representative of the Tarkwa Nsueam Municipal Assembly (TNMA), two representatives from the host communities, the Managing Director of AGAIM and a representative of the EPA. The MAG meets twice a year and can be convened in the event of an emergency" - EM12.

The views of regulatory stakeholders on stakeholder engagement practices in the mining industry are that:

"Mining companies should be made to implement effective and transparent engagement with their stakeholders at all times. There should be a system in place to independently verify reporting arrangements with mining stakeholders"-MinCom 1.

"I think the mining companies should put in place community consultation before each stage of operations, be prepared to modify project plans and practices according to the consultations. They should also develop and maintain appropriate community consultation through all stages of exploration, extraction, waste disposal, and mine closure" - EPA.

"Mining companies should make sure that appropriate systems are in place for the promotion of interaction with affected stakeholders. They have to make sure that all the minorities as well as the marginalised groups have equitable and culturally appropriate means of engagement" - MinCom 2.

"As required by law, in their environmental impact assessment (EIA), mining companies provide technical information about the potential effects of their activities from time to time. Management of waste, rehabilitation procedures and socio-economic and environmental impacts of mining activities should all be communicated to their host communities. They can't take them for granted" - EPA.

\subsection{Stakeholders' Perspectives on EAP}

The empirical evidence from this study have revealed a major motivating factor for EAP in the mining industry which is the fact that EAP forms part of the regulatory requirement for acquiring an operating permit as well as a social license. Interviewees were confident that the motivation for mining firms to engage in EAP is not based on a single factor but a multiplicity of factors. From the interviews, several factors surfaced. On one hand, most mining firms attributed their commitment towards EAP to be a core value, drawn from responsible mining. Most of the mining firms claimed that care for the environment in which they operate forms a focal point in their core values and therefore, drives their actions towards EAP.

Other stakeholders on the other hand, again, commending mining firms for their efforts towards EAP, did not believe that if left on their own, these same mining firms would care so much about the environment. This is evident of coercive isomorphism rather than mimetic or normative. They argued that the presence of regulatory requirements and their associated penalties have been the main drive behind mining firms' commitment towards EAP. Some further pointed out that, "the mining firms are in business simply to maximise profit, and they 
would do whatever it takes to achieve that", EC1. Therefore, "even when it seems they are caring so much for the environment, they simply do so not out of empathy, but, in the long run, they seek to advance their profit position" - EC2.

Pressure from mining communities also surfaced as one of the major factors that spur mining firms on towards EAP. The majority of the stakeholders, other than the mining firms themselves, attributed the mining firms' efforts toward EAP to regulation. So, in effect, the key drivers of EAP are regulatory requirements, core values, and pressure from communities. Table 3 provides a summary of the stakeholders' perspectives on EAP concerning the motivation for EAP, the effectiveness of EAP, firm performance assessment, and stakeholder engagements.

Table 3. Summary of stakeholders' perspectives of EAP in the mining sector

\begin{tabular}{|c|c|c|c|c|}
\hline \multirow{2}{*}{$\begin{array}{l}\text { Stakeholder } \\
\text { Group }\end{array}$} & \multicolumn{4}{|c|}{ Stakeholders' Perspectives of EAP } \\
\hline & $\begin{array}{c}\text { Motivation for } \\
\text { EAP }\end{array}$ & Effectiveness of EAP & $\begin{array}{c}\text { Firm Performance } \\
\text { Assessment }\end{array}$ & $\begin{array}{l}\text { Stakeholder } \\
\text { Engagements }\end{array}$ \\
\hline $\begin{array}{l}\text { Regulatory } \\
\text { bodies (i.e. } \\
\text { Minerals } \\
\text { Commission, } \\
\text { EPA) }\end{array}$ & $\begin{array}{l}\text { - Pollution } \\
\text { control } \\
\text { - Regulatory } \\
\text { enforcement } \\
\text { - Emission } \\
\text { reduction } \\
\text { - Tailings } \\
\text { management } \\
\text { - Operating } \\
\text { license } \\
\text { - Benefits that } \\
\text { outweigh } \\
\text { costs }\end{array}$ & $\begin{array}{l}\text { - Achievement of } \\
\text { environmental targets } \\
\text { - Reduction of } \\
\text { incidents } \\
\text { - Environmental safety } \\
\text { of mining } \\
\text { communities } \\
\text { - Regulatory } \\
\text { compliance } \\
\text { - Submission of EAP } \\
\text { reports } \\
\text { - Application of } \\
\text { current } \\
\text { environmental } \\
\text { reporting standards }\end{array}$ & $\begin{array}{l}\text { - Prompt regulatory } \\
\text { payments } \\
\text { - Regular permit } \\
\text { and license } \\
\text { renewal } \\
\text { - Submission of } \\
\text { returns } \\
\text { - Contribution to } \\
\text { safe human living }\end{array}$ & $\begin{array}{l}\text { - Representative } \\
\text { nature of } \\
\text { stakeholder } \\
\text { meetings } \\
\text { - Stakeholder } \\
\text { consultations } \\
\text { - Stakeholder } \\
\text { access to EAP } \\
\text { reports }\end{array}$ \\
\hline $\begin{array}{l}\text { Mining Firms } \\
\text { (i.e. Mining } \\
\text { concession } \\
\text { holders, mining } \\
\text { firms' } \\
\text { environmental } \\
\text { managers) }\end{array}$ & $\begin{array}{l}\text { - Core values } \\
\text { - Financial } \\
\text { performance } \\
\text { - Regulatory } \\
\text { requirement } \\
\text { - Environmenta } \\
1 \text { safety } \\
\text { - Corporate } \\
\text { environmental } \\
\text { strategy and } \\
\text { policy } \\
\text { - Firm } \\
\text { reputation }\end{array}$ & $\begin{array}{l}\text { - Achievement of } \\
\text { environmental targets } \\
\text { - Reduced } \\
\text { environmental } \\
\text { damage costs } \\
\text { - Environmental audit } \\
\text { of suppliers } \\
\text { - Improved tailings } \\
\text { management } \\
\text { - Eased accessibility to } \\
\text { funds and investors } \\
\text { - Improved staff } \\
\text { orientation on EMS }\end{array}$ & $\begin{array}{l}\text { - Energy } \\
\text { conservation } \\
\text { - Cost reduction } \\
\text { - Improved } \\
\text { productivity } \\
\text { - Benefits that } \\
\text { outweigh costs } \\
\text { - Improved } \\
\text { profitability }\end{array}$ & $\begin{array}{l}\text { - Stakeholder-fir } \\
\text { m consensus } \\
\text { building } \\
\text { - Continuous } \\
\text { stakeholder } \\
\text { engagements } \\
\text { - Stakeholder } \\
\text { consultations } \\
\text { - Effective } \\
\text { communication } \\
\text { mechanisms } \\
\text { - Documentation } \\
\text { of stakeholder }\end{array}$ \\
\hline
\end{tabular}


- Benefits that outweigh

costs procedures

- Dissemination of

EAP reports

- Application of current environmental reporting standards

\begin{tabular}{|c|c|c|c|c|}
\hline & & $\begin{array}{l}\text { current } \\
\text { environmental } \\
\text { reporting standards }\end{array}$ & & \\
\hline $\begin{array}{l}\text { Community } \\
\text { Partners }\end{array}$ & $\begin{array}{l}\text { - Environmenta } \\
1 \text { complaints } \\
\text { - Environmenta } \\
1 \text { damage } \\
\text { - Environmenta } \\
1 \text { safety } \\
\text { - Social license } \\
\text { - Firm } \\
\text { reputation }\end{array}$ & $\begin{array}{l}\text { - Compensation for } \\
\text { farmers or } \\
\text { landowners } \\
\text { - Reduction in } \\
\text { environmental } \\
\text { damages } \\
\text { - Provision of social } \\
\text { amenities } \\
\text { - Employment } \\
\text { opportunities }\end{array}$ & $\begin{array}{l}\text { - Less } \\
\text { environmental } \\
\text { risks posed } \\
\text { - The improved } \\
\text { livelihood of } \\
\text { indigenes } \\
\text { - Fair compensation } \\
\text { packages }\end{array}$ & $\begin{array}{l}\text { - Stakeholder } \\
\text { consultations } \\
\text { - Stakeholder } \\
\text { access to EAP } \\
\text { reports }\end{array}$ \\
\hline $\begin{array}{l}\text { Environmental } \\
\text { consultants (i.e. } \\
\text { Mining experts) }\end{array}$ & $\begin{array}{l}\text { - Community } \\
\text { risk reduction } \\
\text { - Regulatory } \\
\text { requirement } \\
\text { - Social } \\
\text { requirement } \\
\text { - Benefits that } \\
\text { outweigh } \\
\text { costs }\end{array}$ & $\begin{array}{l}\text { - Regulatory } \\
\text { compliance } \\
\text { - Application of } \\
\text { current } \\
\text { environmental } \\
\text { reporting standards }\end{array}$ & $\begin{array}{l}\text { - Prompt response } \\
\text { to abnormal } \\
\text { operating } \\
\text { conditions } \\
\text { - Reduction in } \\
\text { operating costs } \\
\text { - Meeting } \\
\text { regulatory } \\
\text { requirements } \\
\text { - Meeting } \\
\text { community needs }\end{array}$ & $\begin{array}{l}\text { - Stakeholder } \\
\text { consultations } \\
\text { - The success of } \\
\text { jointly decided } \\
\text { projects } \\
\text { - Stakeholder } \\
\text { access to EAP } \\
\text { reports }\end{array}$ \\
\hline $\begin{array}{l}\text { Mining } \\
\text { Associations }\end{array}$ & $\begin{array}{l}\text { - Industry } \\
\text { practice } \\
\text { - Industry } \\
\text { sensitivity }\end{array}$ & $\begin{array}{l}\text { - Regulatory } \\
\text { compliance } \\
\text { - Application of } \\
\text { current } \\
\text { environmental } \\
\text { reporting standards } \\
\text { - Focus on green } \\
\text { initiatives }\end{array}$ & $\begin{array}{l}\text { - Compliance to } \\
\text { industry } \\
\text { conditions } \\
\text { - Improved } \\
\text { contribution to } \\
\text { industry } \\
\text { development } \\
\text { - Improved access } \\
\text { to funding } \\
\text { - Adaptability to } \\
\text { changing } \\
\text { environmental } \\
\text { conditions }\end{array}$ & $\begin{array}{l}\text { - Stakeholder } \\
\text { consultations } \\
\text { - Stakeholder } \\
\text { access to EAP } \\
\text { reports }\end{array}$ \\
\hline
\end{tabular}

meetings

- The success of jointly decided projects

Source: Author's construct based on documentary analysis and interview responses (2018) 


\section{$\Lambda$ Macrothink}

International Journal of Accounting and Financial Reporting ISSN 2162-3082

Table 3 confirms that in the mining communities, some efforts have been made towards engaging in EAP. Further probing was made to establish how effectively mining firms are carrying out their EAP. It was evident that some gaps or lapses exist between mining firms' EAP and the expectations of mining communities. From the perspectives of the regulatory bodies, it appeared there were no lapses, and that all regulatory requirements are being fulfilled by the large-scale commercial production mining firms but not by the artisanal and small-scale miners. This feedback did not come as a surprise. It goes a long way to confirm how the presence of regulations motivates mining firms to be environmentally accountable. It brought to bear how potentially chaotic the mining sector would be if the element of the regulation is taken out. As one officer with the MinCom Inspectorate Division puts it, "the mining industry is the most regulated industry”.

\subsection{Drivers, Outputs and Outcomes of EAP}

Based on the empirical material and analysis of EAP in the mining industry from the perspectives of multiple stakeholders, Table 4 describes the drivers (the "why" of EAP), the outputs (the "how" of EAP) and the outcomes (the "benefits") of EAP in the mining industry. The drivers are the motivations for mining firms to engage in EAP. They are the reasons 'why' mining firms would want to be socially and environmentally accountable. The outputs refer to what mining firms do to demonstrate that they are socially and environmentally accountable. They are the 'how' of EAP. The outcomes are the 'benefits' that accrue once mining firms engage in EAP. The outcomes are beneficial to all stakeholders in the mining industry. In the end, engaging in EAP creates a 'win-win' situation for all.

\section{Conclusion and Recommendations}

Responses from the various stakeholder interviews conducted have confirmed that to gain 'operating and social licenses', mining firms do take stakeholder engagement quite seriously. As part of regulatory requirements, mining firms are supposed to meet with the mining communities at least once before actual work begins. At that same meeting, the concerns of these communities are tabled, and the mining firms let the communities know what they can also do to improve the wellness of these communities. A concern that some stakeholders expressed, however, was that some mining firms tend to neglect these very communities after they have gained a hold within. Members of the community accused most mining firms of neglect, and in effect, cause a lot of problems for these firms. Countering this allegation, virtually all the mining firms have also accused community members of being too demanding and not being realistic with their expectations. Another issue that came up had to do with the fairness in compensating farmers or landowners.

Holistically, there was a convergence in the views of stakeholders that large-scale commercial production mining firms operating in Ghana are making efforts in the quest to achieve social and environmental sanity as well as improve the livelihood of community members. There however existed a diversity in stakeholder views on the degree to which EAP has been properly handled by mining firms. The mining firms believed that they were doing their best for these communities, while, community members expressed a bit of discontentment. These issues aside, community activities that mining firms undertake as part of their EAP include 


\section{Mll Macrothink}

International Journal of Accounting and Financial Reporting

ISSN 2162-3082

2020, Vol. 10, No. 4

but not limited to building water and waste dams to avoid contaminating water bodies, building boreholes, reclaiming the land, planting of trees, building schools, hospitals, providing employment, instituting other internal control measures, community collaborations, among others.

Mining communities should be enlightened on how the mining sector operates. Mining is a capital-intensive sector, and mining firms spend a lot of resources before they even start actual production. Community partners must be reasonable in their demands since most large-scale mining firms are already doing a lot to demonstrate their EAP even though they can do more.

In line with the proposition of Tang-Lee (2016), the study recommends the need for mining companies to strengthen their engagement with indigenes, and not only local elites, and ensure alignment between EAP efforts and the immediate needs of the local communities.

It is recommended that the government should adequately resource the regulatory bodies to strengthen their monitoring and enforcement activities. Regulatory compliance is a major driver of EAP in the mining industry. Punitive measures should be instituted for non-compliance with regulatory requirements to serve as a deterrent. The government's efforts at combating illegal mining activities should be seriously encouraged and supported by all stakeholders, particularly community partners. The study has revealed that the most environmentally unaccountable players in the mining industry are illegal miners.

The study recommends further research to focus on assurance on EAP. This will provide a firm basis of validating the claims by most mining firms that they are socially and environmentally accountable.

\section{References}

Akabzaa, T., \& Darimani, A. (2001). Impact of mining sector investment in Ghana: A study of the Tarkwa mining region. Third World Network, 47-61.

Association of Chartered Certified Accountants [ACCA]. (2007). Social and environmental reporting and the business case. Retrieved 15th May 2016, from www.accaglobal.com/pubs/general/activities

Bendell, J., \& Kearins, K. (2005). The political bottom line: the emerging dimension to corporate responsibility for sustainable development. Business Strategy and the Environment, 14(6), 372-383.

Benston, G. J. (1982). Accounting and corporate accountability. Accounting, Organizations and Society, 7(2), 87-105.

Campbell, B. (2003). Factoring in governance is not enough. Mining codes in Africa, policy reform and corporate responsibility. Minerals \& Energy-Raw Materials Report, 18(3), 2-13.

Candeias, C., Ávila, P., Coelho, P., \& Teixeira, J. P. (2018). Mining activities: health impacts. Reference Module in Earth Systems and Environmental Sciences, 1-21. 


\section{Mll Macrothink}

International Journal of Accounting and Financial Reporting

ISSN 2162-3082

Carter, C. R., \& Jennings, M. (2000). Purchasing's Contribution to the Socially Responsible Management of the Supply Chain. Tempe, AZ: Center for Advanced Purchasing Studies.

Chaabane, A., Ramudhin, A., \& Paquet, M. (2011). Designing supply chains with sustainability considerations. Production Planning \& Control, 22(8), 727-741.

Ciliberti, F., De Haan, J., De Groot, G., \& Pontrandolfo, P. (2011). CSR codes and the principal-agent problem in supply chains: four case studies. Journal of Cleaner Production, 19(8), 885-894.

Cruz, J. M., \& Wakolbinger, T. (2008). Multiperiod effects of corporate social responsibility on supply chain networks, transaction costs, emissions, and risk. International Journal of Production Economics, 116(1), 61-74.

Edgley, C. R., Jones, M. J., \& Solomon, J. F. (2010). Stakeholder inclusivity in social and environmental report assurance. Accounting, Auditing \& Accountability Journal.

Esteves, A. M. (2008). Mining and social development: Refocusing community investment using multi-criteria decision analysis. Resources Policy, 33(1), 39-47.

European Commission. Directorate-General for Energy. (2001). Green Paper: Towards a European strategy for the security of energy supply. Office for Official Publications of the European Communities.

Fiedler, L., \& Kirchgeorg, M. (2007). The role concept in corporate branding and stakeholder management reconsidered: Are stakeholder groups really different?. Corporate Reputation Review, 10(3), 177-188.

Fonseca, A., McAllister, M. L., \& Fitzpatrick, P. (2014). Sustainability reporting among mining corporations: a constructive critique of the GRI approach. Journal of Cleaner Production, 84, 70-83.

Freitas, A. H., \& Magrini, A. (2013). Multi-criteria decision-making to support sustainable water management in a mining complex in Brazil. Journal of Cleaner Production, 47, 118-128.

Ghana Chamber of Mines. (2016). Environmental performance of mining firms in Ghana. Accra.

Gomes, C. M., Kneipp, J. M., Kruglianskas, I., da Rosa, L. A. B., \& Bichueti, R. S. (2014). Management for sustainability in companies of the mining sector: an analysis of the main factors related with the business performance. Journal of Cleaner Production, 84, 84-93.

Gray, R. (1992). Accounting and environmentalism: An exploration of the challenge of gently accounting for accountability, transparency and sustainability. Accounting Organisations and Society, 17(5), 399-426.

Gray, R., Owen, D., \& Adams, C. (1996). Accounting \& accountability: changes and challenges in corporate social and environmental reporting. Prentice Hall. 


\section{$\triangle$ Macrothink}

International Journal of Accounting and Financial Reporting

ISSN 2162-3082

Haigh, M., \& Jones, M. T. (2006). The drivers of corporate social responsibility: A critical review.

Hall, M., Millo, Y., \& Barman, E. (2015). Who and what really counts? Stakeholder prioritization and accounting for social value. Journal of Management Studies, 52(7), 907-934.

Hamann, R. (2003). Mining companies' role in sustainable development: the 'why' and 'how' of corporate social responsibility from a business perspective. Development Southern Africa, 20(2), 237-254.

Hamann, R., \& Kapelus, P. (2004). Corporate social responsibility in mining in Southern Africa: Fair accountability or just greenwash?. Development, 47(3), 85-92.

Hietbrink, J. J. C., Berens, G., \& Van Rekom, J. (2010). Corporate social responsibility in a business purchasing context: The role of CSR type and supplier product share size. Corporate Reputation Review, 13(4), 284-300.

Hillenbrand, C., \& Money, K. (2007). Corporate responsibility and corporate reputation: two separate concepts or two sides of the same coin?. Corporate Reputation Review, 10(4), 261-277.

Hilson, G. (2002). An overview of land-use conflicts in mining communities. Land Use Policy, 19(1), 65-73.

Hilson, G. (2002). The environmental impact of small - scale gold mining in Ghana: identifying problems and possible solutions. Geographical Journal, 168(1), 57-72.

Idowu, S. O. (2009). Professionals' perspectives of CSR: An introduction. In Professionals' Perspectives of Corporate Social Responsibility (pp. 1-8). Springer, Berlin, Heidelberg.

Jenkins, H., \& Yakovleva, N. (2006). Corporate social responsibility in the mining industry: Exploring trends in social and environmental disclosure. Journal of Cleaner Production, 14(3-4), 271-284.

Jones, M. J., \& Solomon, J. F. (2010, March). Social and environmental report assurance: Some interview evidence. In Accounting Forum (Vol. 34, No. 1, pp. 20-31). No longer published by Elsevier.

Karnani, A. (2011). CSR Stuck in a Logical Trap a Response to Pietra Rivoli and Sandra Waddock's “"First They Ignore You...': The Time-Context Dynamic and Corporate Responsibility". California Management Review, 53(2), 105-111.

Kemp, D., Boele, R., \& Brereton, D. (2006). Community relations management systems in the minerals industry: combining conventional and stakeholder-driven approaches. International Journal of Sustainable Development, 9(4), 390-403.

Kemp, D., Owen, J. R., \& Van de Graaff, S. (2012). Corporate social responsibility, mining and "audit culture". Journal of Cleaner Production, 24, 1-10. 


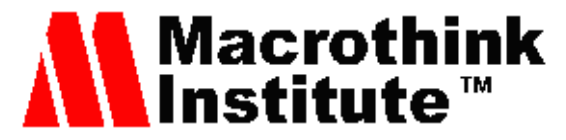

International Journal of Accounting and Financial Reporting ISSN 2162-3082

Larsen, L. (2010). Corporate Social Responsibility in Denmark and the US. Doctoral dissertation, Master thesis, Department of Language and Business Communication, Aarhus School of Business, Aarhus University.

Lodhia, S. (2012). Web-based social and environmental communication in the Australian minerals industry: an application of media richness framework. Journal of Cleaner Production, 25, 73-85.

Lu, Y., \& Abeysekera, I. (2014). Stakeholders' power, corporate characteristics, and social and environmental disclosure: Evidence from China. Journal of Cleaner Production, 64, 426-436.

Majer, M. (2013). The practice of mining companies in building relationships with local communities in the context of CSR formula. Journal of Sustainable Mining, 12(3), 38-47.

Majumdar, S., \& Nishant, R. (2008). Sustainable entrepreneurial support (in supply chain) as corporate social responsibility initiative of large organizations: a conceptual framework. ICFAI Journal of Entrepreneurship Development, 5(3), 6-22.

McWilliams, A., \& Siegel, D. (2001). Corporate social responsibility: A theory of the firm perspective. Academy of Management Review, 26(1), 117-127.

Miles, M. B., Huberman, M. A., \& Saldana, J. (2014). Qualitative Data Analysis: A Methods Sourcebook (3rd ed.). Los Angeles: SAGE Publications, Inc.

Moon, J. (2004). Government as a driver of corporate social responsibility: The UK in comparative perspective.

Muduli, K., Govindan, K., Barve, A., Kannan, D., \& Geng, Y. (2013). Role of behavioural factors in green supply chain management implementation in Indian mining industries. Resources, Conservation and Recycling, 76, 50-60.

Murguía, D. I., \& Böhling, K. (2013). Sustainability reporting on large-scale mining conflicts: the case of Bajo de la Alumbrera, Argentina. Journal of Cleaner Production, 41, 202-209.

Northey, S., Haque, N., \& Mudd, G. (2013). Using sustainability reporting to assess the environmental footprint of copper mining. Journal of Cleaner Production, 40, 118-128.

O’Dwyer, B., Owen, D., \& Unerman, J. (2011). Seeking legitimacy for new assurance forms: The case of assurance on sustainability reporting. Accounting, Organizations and Society, $36(1), 31-52$.

Ogawa, N. (2009). Corporate Code of Conduct of Japanese Transnational Corporations: Analysis of Corporate Social Responsibility in Supply Chain Management.

Parker, L. D., \& Roffey, B. H. (1997). Methodological themes. Accounting, Auditing \& Accountability Journal.

Parsons, R., \& Moffat, K. (2014). Constructing the meaning of social licence. Social Epistemology, 28(3-4), 340-363. 


\section{$\triangle$ Macrothink}

International Journal of Accounting and Financial Reporting

ISSN 2162-3082

Peloza, J. (2006). Using corporate social responsibility as insurance for financial performance. California Management Review, 48(2), 52-72.

Pickett, J., \& Shaeeldin, E. (1990). Comparative advantage in agriculture in Ghana.

Powell, S. M., Davies, M., \& Shearer, H. J. (2009). Motivating corporate social responsibility in the supply chain.

Prno, J., \& Slocombe, D. S. (2012). Exploring the origins of 'social license to operate' in the mining sector: Perspectives from governance and sustainability theories. Resources Policy, $37(3), 346-357$.

PwC. (2016). PwC's Mine 2016. London: PricewaterhouseCoopers.

Ranängen, H., \& Zobel, T. (2014). Exploring the path from management systems to stakeholder management in the Swedish mining industry. Journal of Cleaner Production, 84(1), 128-141.

Rokhmawati, A., Sathye, M., \& Sathye, S. (2015, September). The effect of GHG emission, environmental performance, and social performance on financial performance of listed manufacturing firms in Indonesia. Procedia - Social and Behavioral Sciences, 211(25), 461-470.

Roome, N. (2005). Some implications of national agendas for CSR. Corporate Social Responsibility Across Europe, 317-333.

Rustad, S. A., Østby, G., \& Nordås, R. (2016). Artisanal mining, conflict, and sexual violence in Eastern DRC. Extractive Industries and Society, 3(2). https://doi.org/10.1016/j.exis.2016.01.010

Salam, M. A. (2009). Retracted article: Corporate social responsibility in purchasing and supply chain. Journal of Business Ethics, 85(2), 355-370.

Saunders, M., Lewis, P., \& Thornhill, A. (2009). Research Methods for Business Students. Pearson Education.

Senkel, M. P. (2014). Corporate Social Responsibility (CSR) information disclosure by annual reports: the Deutsche Post-DHL case (1998-2011). Journal of Economics and Business, 17(1), 39-62.

Sinclair, A. (1995). The chameleon of accountability: Forms and discourses. Accounting, Organizations and Society, 20(2-3), 219-237.

Smith, N. C. (2007). Consumers as drivers of corporate responsibility.

Solomon, F., Katz, E., \& Lovel, R. (2008). Social dimensions of mining: Research, policy and practice challenges for the minerals industry in Australia. Resources Policy, 33(3), 142-149.

Steurer, R., Langer, M. E., Konrad, A., \& Martinuzzi, A. (2005). Corporations, stakeholders and sustainable development I: a theoretical exploration of business-society relations. 


\section{Macrothink \\ International Journal of Accounting and Financial Reporting \\ ISSN 2162-3082 \\ 2020, Vol. 10, No. 4}

Journal of Business Ethics, 61(3), 263-281.

Tackie, G., Agyenim-Boateng, C., \& Arthur, C. L. (2017). An examination of environmental accounting and reporting practices of large-scale mining companies in Ghana. ADRRI Journal of Arts and Social Sciences, Ghana, 15(2), 1-22.

Tang-Lee, D. (2016). Corporate social responsibility (CSR) and public engagement for a Chinese state-backed mining project in Myanmar. Resources Policy, 47, 28 -37.

Velásquez, T. A. (2012). Going green: sustainable mining, water, and the remaking of social protest in post-neoliberal Ecuador.

Vintró, C., Fortuny, J., Sanmiquel, L., Freijo, M., \& Edo, J. (2012). Is corporate social responsibility possible in the mining sector? Evidence from Catalan companies. Resources Policy, 37(1), 118-125.

Viveros, H. (2016). Examining stakeholders' perceptions of mining impacts and corporate social responsibility. Corporate Social Responsibility and Environmental Management, 23, $50-64$.

Weng, H.-H., Chen, J., \& Chen, P. (2015). Effects of green innovation on environmental and corporate performance: a stakeholder perspective, Sustainability, 7, 4997-5026.

Westphalen, L. G. (2012). Corporate social responsibility in the mining sector: A win-win situation, Canadian Student Review, Spring, 51-61.

Wilson, S. A. (2015). Corporate social responsibility and power relations: Impediments to community development in post-war Sierra Leone diamond and rutile mining areas. Extractive Industries and Society, 2(4), 704-713.

Wood, D. J., \& Jones, R. E. (1995). Stakeholder mismatching: A theoretical problem in empirical research on corporate social performance. The International Journal of Organizational Analysis.

\section{Copyright Disclaimer}

Copyright for this article is retained by the author(s), with first publication rights granted to the journal.

This is an open-access article distributed under the terms and conditions of the Creative Commons Attribution license (http://creativecommons.org/licenses/by/4.0/) 